\title{
Competencies Learned by the Students through Ambulatory Care Teaching In Undergraduate Medical Education in Gynaecology \& Obstetrics in Different Medical Colleges of Bangladesh: Interns' and Teachers' view
}

\author{
Brig Gen Dr. Iffat Ara', Professor Dr. Md Humayun Kabir Talukder ${ }^{2}$, Dr. Tahmina Nargis ${ }^{3}$
}

\begin{abstract}
This descriptive cross sectional study was carried out to assess the competencies learned by the students through ambulatory care teaching according to teachers' and interns' view in the undergraduate medical education in Gynaecology and Obstetrics in the medical colleges of Bangladesh. Study was conducted on nine medical colleges including five Public medical colleges and four Private medical colleges. Total 58 teachers \& 567 interns participated in the study, and Separate self-administered semi structured questionnaire were used to collect their valuable opinions.

Most of the teachers mentioned that through ambulatory care teaching students are taught: to greet a patient on arrival; to take history; to take consent before examining a patient; to maintain privacy during examining a patient; to do general examination of a patient; to examine a pregnant patient

Most of the interns mentioned that through ambulatory care teaching the competencies learned by the students are: taking history, maintaining confidentiality, maintain privacy during examination, examining a pelvic mass, interpreting investigation reports, making provisional diagnosis. Students also observed the procedure of VIA test, and steps of PAP's test.

The study recommends that all clinical teachers should have clear knowledge about ambulatory care teaching \& every institute should foster feasible teaching and learning environment.
\end{abstract}

Key words: Ambulatory care teaching, Competencies for undergraduate medical students.

\section{Introduction}

Ambulatory care refers to any place where patients are seen in hospital without being admitted in hospital (Dent, J.A. 2005 AMEE Guide No 26). For ambulatory care teaching patients may be available from a variety of sources. There may be new patients attending outpatient clinics, the emergency department or clinical investigation and imaging or can be selected from those newly referred from their GP for outpatient appointments and invited to specially timetabled teaching sessions (Dent, J.A. 2005 AMEE Guide No. 26). Teaching of clinical skills traditionally takes place in hospital wards and outpatient settings. There are varieties of patients in the outdoor. As inpatients tend to be more representative of subspecialty conditions or more critically ill patients, so they

\footnotetext{
${ }^{1}$ Professor \& Head, Department of Gynae \& Obs

Armed Forces Medical College, Dhaka Cantonment, Dhaka

${ }^{2}$ Professor, Curriculum Development \& Evaluation,

Centre for Medical Education, Mohakhali, Dhaka

${ }^{3}$ Assistant Professor, Centre for Medical Education, Mohakhali, Dhaka
}

Address of correspondence: Brig Gen Dr. Iffat Ara

Professor (Gynae \& Obs), Armed Forces Medical College,

Dhaka Cantonment, Dhaka

E-mail: iffatwaleed@gmail.com become less representative of routine medical practice (Fincher \& Albritton, 1993; Seabrook et al., 1997). In Gynecology\& Obstetrics the opportunities can be provided at the Gynaecology outpatient Department (GOPD) where large number of patients with minor ailments are managed, there are also various types of patient available with positive findings. Here the student can learn which patient needs to be admitted and which patient can be treated as an OPD case. At the antenatal clinic pregnant women get antenatal check up and get advice regarding pregnancy problems. They are screened for high risk cases. In the family planning clinics students will be able to understand the various ways of dealing with the patients, counselling the patients and managing the related problems. In gynecological Ultra sonogram department the students can learn the various normal and abnormal ultra-sonological diagnostic techniques. In radiology department they can learn the related various types of radiological techniques \& procedures and how the reports are interpreted. In the infertility clinics they can learn the basic of reproduction and related skills and knowledge according to their level of education. They can even attend the gynaecological oncology clinics to have an idea about it. Another important aspect is the attending of day care surgery, in our setting the important is the $\mathrm{D} \& \mathrm{C}$ and other small surgical procedures. Ambulatory care teaching can give students the opportunity to meet selected patients with problems relevant to their stage of learning.

Bangladesh Journal of Medical Education 2018;9(1):18-20. C 2018 Ara et al., publisher and licensee Association for Medical Education. This is an Open Access article which permits unrestricted non-commercial use, provided the original work is properly cited. 
Increasing student numbers and changes in healthcare delivery are making inpatient settings less ideal for teaching undergraduate students. In fact the teaching and learning without admitting the patient in the hospital is a very important method of teaching where we can get large number of patients $\&$ varieties of patient according to the level of the knowledge and skill required by the undergraduate medical students. On completing the MBBS the newly graduated doctors will do the GP and handle the outpatient. Our aim for the undergraduate students is to make them develop into competent doctors who will be general practitioners not specialists at their graduation.

As the focus of healthcare provision shifts towards ambulatory care, increased attention must now be given to developing opportunities for clinical teaching in this setting

\section{Methodology}

This descriptive cross sectional study was carried out to assess the competencies learned by the students through ambulatory care teaching according to teachers' and students' view in the undergraduate medical education in Gynaecology and Obstetrics in the medical colleges of Bangladesh. Study was conducted on nine medical colleges including five Public medical colleges and four Private medical colleges. The study period was July 2016 to June 2017. Total 58 teachers \& 567 interns participated in the study, and gave their valuable opinions. Convenience sampling technique was used. Separate self-administered semi structured questionnaire were used for the teachers and the interns. Prior permission was taken from the respective authority to conduct the study on their colleges. The questionnaire was anonymous and after being well informed about study those who were voluntarily participated were the respondents. Data were analysed according to objectives and presented in the tables.

\section{Results}

Table 1: Distribution of teachers by their opinion regarding competencies taught in gynaecology at ambulatory care teaching site $\mathrm{n}=58$

\begin{tabular}{|l|c|c|}
\hline $\begin{array}{l}\text { Statements regarding the } \\
\text { competencies taught at the } \\
\text { ambulatory care teaching sites }\end{array}$ & $\begin{array}{c}\text { Agree } \\
\mathbf{\%}\end{array}$ & $\begin{array}{c}\text { Not agreed } \\
\mathbf{\%}\end{array}$ \\
\hline $\begin{array}{l}\text { Students are taught to greet a patient } \\
\text { on arrival }\end{array}$ & $52(89.66)$ & $6(10.34)$ \\
\hline Students are taught to take history & $52(89.66)$ & $6(10.34)$ \\
\hline $\begin{array}{l}\text { Students are taught to take consent } \\
\text { before examining a patient }\end{array}$ & $51(87.93)$ & $7(12.07)$ \\
\hline $\begin{array}{l}\text { Students are taught to maintain } \\
\text { privacy during examining a patient }\end{array}$ & $50(86.21)$ & $8(13.79)$ \\
\hline $\begin{array}{l}\text { Students are shown to do general } \\
\text { examination of a patient }\end{array}$ & $51(87.93)$ & $7(12.07)$ \\
\hline $\begin{array}{l}\text { Students are shown to examine a } \\
\text { pregnant patient }\end{array}$ & $53(91.38)$ & $5(8.62)$ \\
\hline
\end{tabular}

Table 2: Distribution of the of the interns by their opinion about the knowledge $\&$ competencies acquired by students in ambulatory care teaching $\mathrm{n}=567$

\begin{tabular}{|l|c|c|}
\hline $\begin{array}{l}\text { Statements regarding the knowledge } \\
\text { \& competencies taught at the } \\
\text { ambulatory care teaching sites }\end{array}$ & $\begin{array}{c}\text { Agree } \\
\%\end{array}$ & $\begin{array}{c}\text { Not agreed } \\
\%\end{array}$ \\
\hline Student learned to take history & $482(85)$ & $85(15)$ \\
\hline $\begin{array}{l}\text { Student learned to maintain } \\
\text { confidentiality }\end{array}$ & $466(82.19)$ & $101(17.81)$ \\
\hline $\begin{array}{l}\text { Student learned to maintain privacy } \\
\text { during examination }\end{array}$ & $484(85.36)$ & $83(14.64)$ \\
\hline $\begin{array}{l}\text { Student learned to examine a pelvic } \\
\text { mass }\end{array}$ & $401(70.72)$ & $166(29.28)$ \\
\hline $\begin{array}{l}\text { Student learned to interpret } \\
\text { investigation reports }\end{array}$ & $463(81.66)$ & $104(18.34)$ \\
\hline $\begin{array}{l}\text { Student learned to make provisional } \\
\text { diagnosis }\end{array}$ & $451(79.54)$ & $116(20.46)$ \\
\hline $\begin{array}{l}\text { Student has seen the procedure of } \\
\text { VIA test }\end{array}$ & $277(48.85)$ & $290(51.15)$ \\
\hline $\begin{array}{l}\text { Student has learned the steps of } \\
\text { PAP's test }\end{array}$ & $297(52.38)$ & $270(47.62)$ \\
\hline
\end{tabular}

\section{Discussion:}

Most of the knowledge, skills, and attitudes required for professional practice can be learnt in ambulatory care settings, since the ambulatory care teaching sites can provide a rich source of patients with positive findings who are not critically ill and can be handled by the students. Rapport building with the patients is one of the vital points for medical education. If the patient is not cooperative then it is impossible for the student to gain necessary level of training and experience to be a qualified doctor (Chip et al.). Therefore the student should learn the art to take the patient into confidence addressing the emotional aspects of the patient. History taking is the most important clue to the diagnosis and treatment of the patient and it is the first step to be learned by a medical student to be a doctor. The first step of approaching a patient is to greet the patient and build a rapport before taking the history, $89.5 \%$ teachers said that they have taught the students to greet a patient. $86.2 \%$ teachers said that they have taught the students to take history. The opinion of the students was, $85.2 \%$ students learned to take antenatal history \& $88.2 \%$ students learned to take the gynaecology history.

It is very important to supervise the medical students during physical examination of the patients to safeguard the safety of the patients. There should be policy outlines to be followed when supervising medical students. The goal should be to promote safe patient care and maximize student's development of skills, knowledge, and attitudes needed to enter the practice of medicine. Taking consent before physical examination and maintaining privacy is very important. $84.2 \%$ teachers said that they have taught the students to take consent before undergoing physical examination.

Bangladesh Journal of Medical Education 2018;9(1):18-20. 
$85.7 \%$ teachers said that they have taught and $83.3 \%$ students said that they have learned to maintain privacy during examination. $87.9 \%$ teachers said that they have allowed the students to examine a patient under their supervision, $88.2 \%$ students did the physical examination on antenatal patients and $81.9 \%$ students could examine a gynaecological case under the teacher's supervision. 78.7\% students said that teachers have encouraged them to present the case history and their findings. The teachers (58.4\%) took formative \& $54.2 \%$ took summative assessments with feedback (83.7\%). 69.5\% students said that they had assessment and feedback on their learning.

The students should learn how to plan investigations \& how to interpret them. They should learn to make provisional diagnosis, differential diagnosis and then come to a final diagnosis. In the study it was found that according to the opinion of $86.2 \%$ teachers, the students were encouraged to interpret investigation reports and $75.9 \%$ students said that they have learned to interpret the investigations. The mean $\mathrm{SD}$ in both the cases is $>3$.

Counselling a patient respecting their emotional aspect is an art. Breaking bad news or reassurance needs expertise. Over the course of a career, a busy clinician may disclose unfavourable medical information to patients and families many thousands of times (Fallowfield L, Lipkin M, Hall A). Breaking bad news to cancer patients is inherently aversive, described as "hitting the patient over the head" or "dropping a bomb"( Miyaji N) Breaking bad news can be particularly stressful when the clinician is inexperienced, the patient is young, or there are limited prospects for successful treatment. (Ptacek JT, Eberhardt TL.) This art of dealing with the patients is essential to be a good physician. In the study it was found that according to the statement of the students almost $100 \%$ have attended the counselling session in the family planning department.

\section{Conclusion}

In outpatient Department since there are abundance of patients so we can arrange more patients for the students to learn various tasks such as abdominal examination in a pregnant patient or examination of an abdominal lump. For gynaecology \& and obstetrics as well as other clinical subjects ambulatory care teaching can improve the quality of doctors. All clinical teachers should have clear knowledge and understanding about ambulatory care teaching \& every institute should foster feasible clinical teaching and learning environment in the ambulatory care setting.

\section{References}

1. Chipp, E, Stonely, S \& Cooper, K. 2004, Clinical placement for medical students: factors affectingpatient involvement in medical education, Medical Teacher, vol. 26, no.2, pp. 114-119.

2. Dent, J. A. 2005. Amee Guide No. 26: Clinical Teaching in Ambulatory Care Settings: Making the Most of Learning Opportunities with Outpatients. Medical Teacher, 27, 302-315.

3. Fallowfield L, Lipkin M, Hall A. 1998. Teaching senior oncologists communication skills: results from phase I of a comprehensive longitudinal program in the United Kingdom. JClin Oncol;16:1961-1968.

4. Fincher, R. M. E., \& Albritton, T. A. 1993. The Ambulatory Experience for Junior Medical Students at the Medical College of Georgia, Teaching and Learning in Medicine, 5, 210-213.

5. Miyaji N. 1993. The power of compassion: truth-telling among American doctors in the care of dying patients. Soc Sci Med ;36:249-264.

7. Ptacek JT, Eberhardt TL. Breaking bad news. 1996. A review of the literature. JAMA ;276:496-502.

8. Seabrook, M. A., Lawson, M., \& Baskerville, P. A. 1997. Teaching and Learning in Day Surgery Units: A UK Survey. Medical Education, 31, 105-108.

Bangladesh Journal of Medical Education 2018;9(1):18-20. 